\title{
Jogos e brincadeiras: tempos, espaços e diversidade
}

\author{
Laudeth Alves dos Reis* \\ Universidade Federal do Triângulo Mineiro \\ Wagner Wey Moreira** \\ Universidade Federal do Triângulo Mineiro \\ Natalia Papacidero Magrin*** \\ Universidade Federal do Triângulo Mineiro \\ Regina Simões**** \\ Universidade Federal do Triângulo Mineiro
}

Jogos e brincadeiras: tempos, espaços e diversidade, é uma obra coletiva organizada em dez capítulos por Tizuko Morchida Kishimoto e com prefácio de João Amado, professor da Universidade de Coimbra.

A autora destaca que a publicação é fruto de dissertações e teses defendidas entre 2000 e 2010 na Faculdade de Educação da USP e de investigações com foco em aspectos lúdicos. Os estudos estão estruturados prioritariamente em pesquisas qualitativas, ancoradas em abordagens como a etnográfica e a análise documental. A obra possui abrangência sobre o jogo, o brincar e o brinquedo, situados no contexto histórico e na diversidade cultural brasileira, explorando as potencialidades educativas nos âmbitos formais e informais. Permite compreender a essência da atividade lúdica e contribui para o fomento de políticas públicas legitimando à criança o direito de brincar.

O primeiro capítulo, denominado "Pesquisas sobre brinquedo no início do século XX", aborda o estudo do lúdico e sua compreensão nos contextos político e educacional que instigaram os pesquisadores a identificar a preferência dos brinquedos entre crianças do ensino primário nas cidades de Belo Horizonte e de São Paulo. Investiga a relevância do brincar nesse período escolar, assim como as teorizações ali adotadas. Evidencia a imagem de uma criança imatura, em que o brincar está direcionado ao preparo e ou antecipação do futuro na ação lúdica, realidade ainda presente na contemporaneidade.

"Felicidade Guerreira: brincar no quilombo", reflete a constituição histórica dos quilombos contemporâneos e destaca as formas de brincar que perpetuaram e se revelaram no cotidiano de seus habitantes e na escola. Através do estudo de caso etnográfico, evidencia a necessidade de redimensionar os currículos, ainda em formato tradicional - único e padronizado - e reitera a potencialidade do brincar, do lúdico, considerando-os processos dinâmicos e importantes para a preservação da História e da Cultura, ao mesmo tempo em que as transforma e as reinventa. 
O texto, "Jogos de tabuleiro: análise na perspectiva histórica", foca a origem dos jogos. Utiliza dois jogos de tabuleiros numa versão (posteriormente industrializada, mas mantendo sua originalidade) de jogos indianos que visavam o ensino de valores e crenças espirituais da cultura hindu, identificando e analisando sua materialidade (peças do tabuleiro) e imaterialidade (figuras representativas de diferentes sentimentos e situações habituais), os quais imitam diferentes gestos da vida diária, emergindo representações e significações contextualizadas, além de permitir apropriar-se de elementos legíveis do real e imaginário das sociedades de origem desses jogos.

O quarto capítulo, "O lúdico na época de Anchieta", se apropria de documentos da época como cartas jesuíticas, gravuras e escritos de viajantes, pautando sua análise acerca dos jogos no Renascimento, na Igreja e na Companhia de Jesus. Embora nesse período as crianças fossem consideradas tábulas rasas, Anchieta procurou compreender os indígenas e propôs que os conhecimentos formais fossem vivenciados por meio de jogos educativos, apropriando-se de uma metodologia ativa que não rompesse com os seus hábitos, costumes, língua, rituais e crenças.

"O brincar na formação inicial de pedagogos", apresenta um estudo de caso envolvendo o desenrolar de um processo de formação com 57 discentes do curso de Pedagogia, os quais puderam analisar a importância do brincar no aprendizado infantil, abrangendo as concepções e fundamentações teóricas, a relevância das escolhas institucionais, além da utilização dos materiais junto às crianças. A experiência proporcionou aos discentes compreender a relação entre a teoria e a prática vivenciada durante os momentos formais (entrevistas) e os informais (jogos, oficinas e conversas).

"Brincar: oportunidade lúdica nos tempos livres da criança?" mostra a escassez de tempo livre destinado às brincadeiras espontâneas, além da crescente institucionalização da criança. Com base em estudo de caso de orientação etnográfica, a pesquisa foi realizada em jardins de infância estatais, os quais possuem horários prolongados, entendidos como tempo pós-letivo ou tempo livre da criança - após o término da aula - constatou que esses prolongamentos de horários não oportunizam o brincar espontâneo, pois priorizam as atividades convencionais.

No sétimo capítulo, a investigação denominada "Brinquedos e gênero na Educação Infantil: estudo etnográfico", objetivou identificar, segundo a perspectiva foucaultiana, as diferentes formas de representação de gênero produzidas no contexto da Educação Infantil. Destaca que uma vez (re)conhecendo-as há a possibilidade de desconstruir o fomento de discriminações. Evidencia que os corpos vão sendo disciplinados e condicionados, como bonecas serem destinadas apenas às meninas e carrinhos aos meninos.

"O lúdico e a emergência da literacia em creche", é uma investigação-ação sobre a criança, com vistas a garantia de produção de novos conhecimentos, assim como a transformação dos envolvidos nesse processo de escolarização. Discute os efeitos do brincar na emergência da literacia, a partir da criação de ambientes educativos em que seja reconhecida a participação ativa da criança. Revela que ao brincar as crianças fazem inúmeras descobertas e desde a mais tenra idade têm contato com a linguagem escrita e se apropriam desta para efeitos de comunicação. 
O nono capítulo "Mukashi banashi: narrativas antigas japonesas e transmissão cultural", investiga a transmissão das narrativas infantis entre os membros de famílias nikkeis de Mogi das Cruzes/SP. A investigação possibilitou uma análise mais apurada da transmissão dos mukashi banashi, que são histórias infantis difundidas oralmente pelas gerações, concluindo que está enfraquecido pelo advento da modernidade e irrelevância exposta frente ao grupo investigado.

O último capítulo "Classificações de objetos lúdicos: sistema COL na brinquedoteca", trouxe estudos que tratam da investigação dos usos dos sistemas de classificação de objetos lúdicos e sua aplicabilidade no contexto das bibliotecas, brinquedotecas ou centros comprometidos com a cultura lúdica.

Concluímos que o livro permite reflexões oportunas sobre a essência da cultura lúdica, possibilitando ampla visão da natureza do jogo, do brincar e do brinquedo, assim como seu potencial educativo nos diferentes espaços da educação formal e informal. Constitui-se referência para outros trabalhos que desejam difundir e aprofundar a discussão sobre essa temática, além de direcionar possíveis e necessárias mudanças que envolvam as políticas públicas. Indicamos a leitura da obra, pois traz à tona apontamentos que nos instigam a continuar no propósito da defesa de uma Educação Infantil que possa ser reinventada a partir da compreensão da essência da atividade lúdica.

\section{Referência}

KISHIMOTO, T. M.; SANTOS, M. W. (org.). Jogos e brincadeiras: tempos, espaços e diversidade (Pesquisa em Educação). São Paulo: Cortez, 2016.

* Mestre em Educação pela Universidade Federal do Triângulo Mineiro, Uberaba, Minas Gerais, Brasil.

** Professor doutor da Universidade Federal do Triângulo Mineiro, Uberaba, Minas Gerais, Brasil.

*** Mestre em Educação Física pela Universidade Federal do Triângulo Mineiro, Uberaba, Minas Gerais, Brasil.

***** Professora doutora da Universidade Federal do Triângulo Mineiro, Uberaba, Minas Gerais, Brasil.

\section{Correspondência}

Wagner Wey Moreira - Universidade Federal do Triângulo Mineiro, Departamento de Ciências do Esporte. Av. Getulio Guaritá, 159, Abadia. CEP: 38025440. Uberaba, Minas Gerais, Brasil.

E-mail: laudeth.alves@gmail.com - weymoreira@uol.com.br - natimagrin@hotmail.com - reginasimoes58@gmail.com

Recebido em 07 de junho de 2017

Aprovado em 05 de dezembro de 2017 
